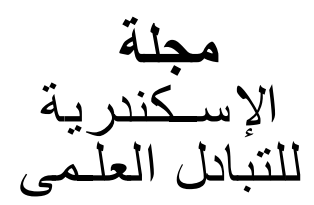

\begin{tabular}{|c|c|c|}
\hline 2007 & يوليو - سبتمبر & مجلد 28 \\
\hline
\end{tabular}

والحخثــة لإنتساج قطع فنيسة مختلفـة تم عرضـها في معـرض لبيـع هـذه

المنتجات.

وتم إستبعاد بعض المهارات اليدوية مثل الكروشيه والتريكو لعدم

إقبال المكفوفات على التدريب عليها وعدم ملاءمتها لنوع الإعاقة.

\section{المقدمة ومشكلة البحث}

تقاس حضارة المجتمع بقدرما يعطيه الفرد من حقوق وما يقدم إليه

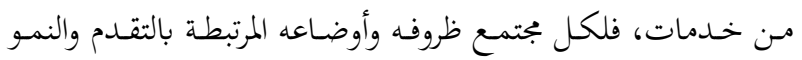

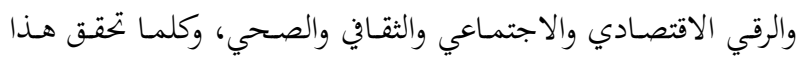

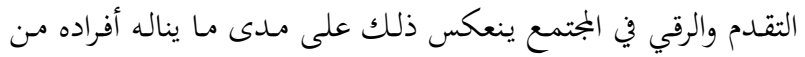

$$
\text { فئات العمر المختلفة من رعاية وعناية. }
$$

ويعتبر المكفوفات مـن فئات المجتمع التي أصاها قدر من الإعاقة

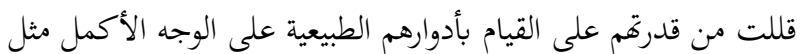

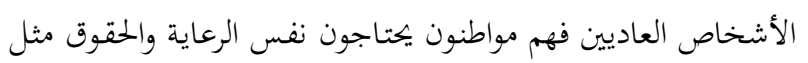

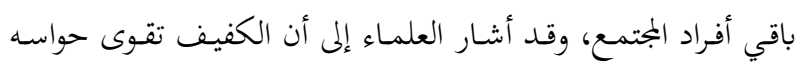
السليمة لتعويض نقص النظر، كما تقوى ذاكرته وحاسة اللمس بمجرد

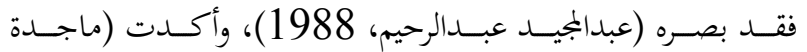
مصطفى، 1981) أنه يمكن الاعتماد على حاسة اللمس في الإدراك والتعبير كمدخل لأسلوب يؤدي للتعبير بالرسم. معن.

وتشـير الإحصـائيات والتقـارير إلى أن مصـر تخسـر سـنوياً 180

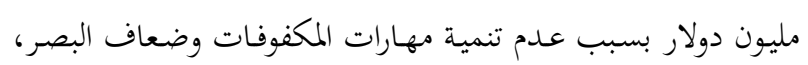

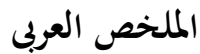

أجريت هذه الدراسة على عينة من المكفوفات وعددهن 45 كفيفة

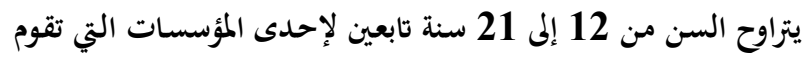

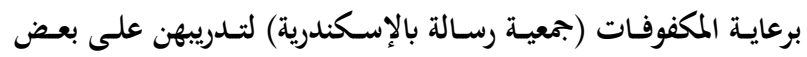

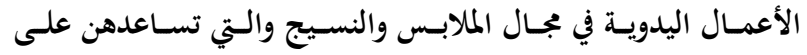

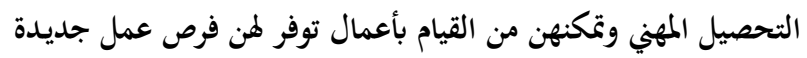

$$
\text { في مجال الملابس والنسيج. }
$$

وقد تم تـدريبهن وإكسـابهن العديد مـن المهارات المعرفيـة واليدويـة والاقتصـادية في مجـال الملابسـ والنسـيج منهـ (التريكسو والكروشسيه

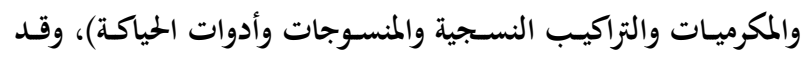

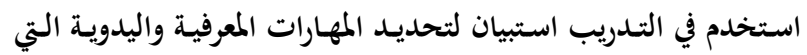

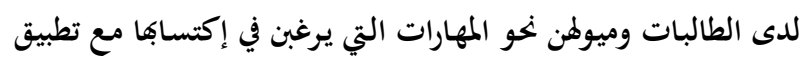
برنامج تدريبي لتنمية المهارات الطالبات المعرفية واليدوية. وتم تحديـد المهارات مـن قبل الكفيفات من خـلال اختبار مهاري

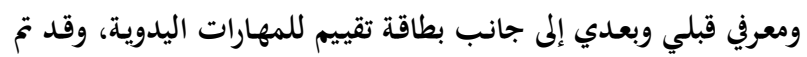
عرض الاختبار وبطاقة التقييم على مجموعة متخصصة من المحكمين. وقـــ أوضـحت نتـائج الدراسـة الميدانيـة أن جميع الكفيفـات ليس

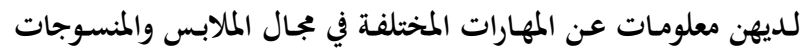

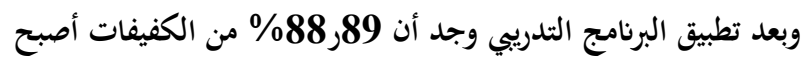

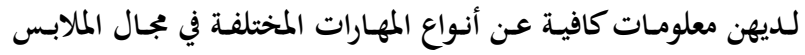
والمنسوجات. وقد أسفرت الدراسة عن إقبال المكفوفات على أشغال التراكيب

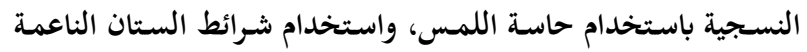


1- خلق جيل جديد من المكفوفات القادرات على إقامة مشروعات متناهية الصغر من خلال برنامج تدريبي.

2- تنمية بعض المهارات المعرفية في مجال الملابس والنسيج والأشغال الفنية.

3- تنمية بعض المهارات اليدوية في مجال الملابس والنسيج والأشغال الفنية التي تناسب المكفوفات.

4- تقدير أثر تلك المهارات على زيادة الثقة بالنفس. 5- دراسة الجدوى الاقتصادية للمنتجات اليدوية التي ينفذها المكفوفا

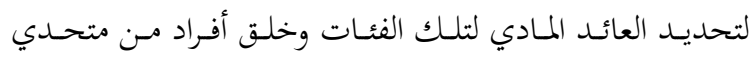
الإعاقة.

\section{المصطلحات العلمية}

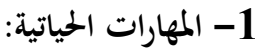

يشير Signorelli, V.A. 1991 أن المهارات الحياتية هي مجموعة المهارات التي تمكن الفرد من التكيف على نحو إيجابي في محيطه

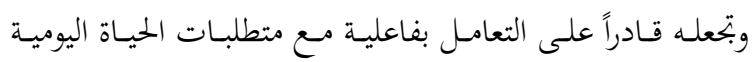
وتحديداها بما يساعد على تعزيز الصحة الجسمية والعقلية والنفسية

والاجتماعية.

ويضيف هينجر (Henger, D, 1992) بأهـا بجموعة المهارات المرتبطة بالبيئة التي يعيش فيها الفرد وما يتصل بها من معارف وقيم

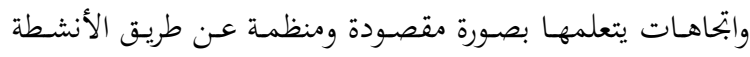
والتطبيقات العملية، وتهدف إلى بناء شخصيته المتكاملة بالصورة

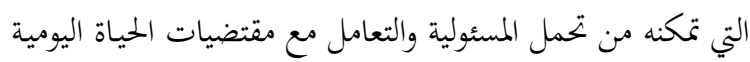
بنجاح وتجعل منه مواطناً منتجاً.

وتنفـل فاطمـة مصـطفى (2001) عـن سـنجر (Singer) بأهــا بمموعـة مهارات الحيـاة اليوميـة التي يحتاجها ذوي الاحتياجـات الخاصة لمساعدقمم على ممارسة حياتم بصورة طبيعية.

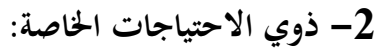

عرف مركز المعلومات ودعم اتخاذ القرار (2005) أن في المجتمع أفراد لهم احتياجـات خاصـة تختلف عـن باقي احتياجـات أفراد المجتمع وتتمثل هذه الاحتياجات في برامج أو خدمات أو أجهزة أو تعديلات وتحدد طبيعة هذه الاحتياجات الخصائص التي يتسم
موضـحةً أن الفـرص أمـام الكفيـف كبـيـة للانخـراط في سـوق العمل (جريدة الشرق الأوسط، 2006)

ويعتبر الاقتصـاد المنتزلي أحســ العلوم التطبيقيـة الـتي قهـتم بتنميـة

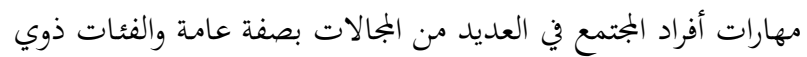
الاحتياجات الخاصة بصفة خاصة حتى يشعروا بأفم جزء لا يتجزأ في

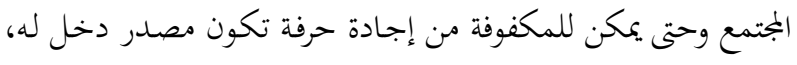

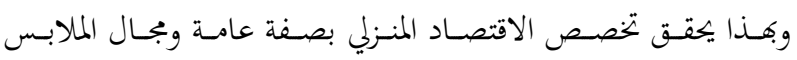
والمنسوجات بصفة خاصة أهدافه الرئيسية لخدمة المجتمع بكافة طوائفه وخاصة المكفوفات. وانطلاقاً من أهمية المهارات المختلفة ومهارات الملابس والنسيج في حياة الفرد لما لما من جوانب هامة لا يمكن إخفاقها فقد رؤي ضرورة وضع برنامج لتنمية بعض المهارات الخاصة بمجال الملابس والمنسوجات

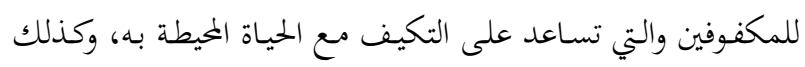

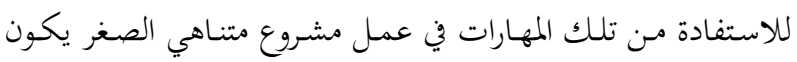
مصدر دخل ثابت له.

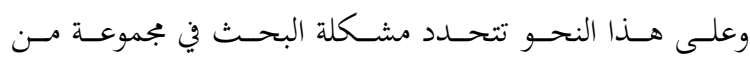

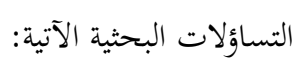
1- مـا مـدى المـامهن ببعض مهارات الملابس والمنسوجات اليدوية واللغوية والحسية والاقتصادية.

2- مـا قـدرة تلـك الفئهة على اتقـان مهـارات الملابس والمنسـوجات المختلفة بعد التدريب الجيد.

3- ما تأثير هذه النوعية من مهارات الملابس والمنسوجات على زيادة الثقة بالنفس.

\section{اهيمة البحث}

ترجع أهمية الدراسة إلى تنمية الجانب المعرفي والمهاري والاقتصادي

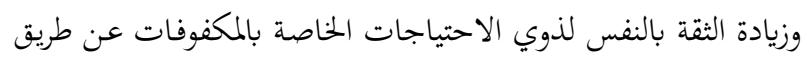

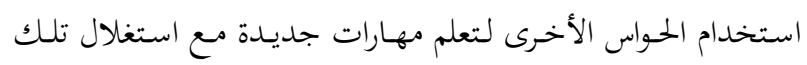
المهارات لفتح ججالات جديدة للعمل من خلال عمل مشروع صغير أو متناهي الصغر. 
الدراسة على (35) كفيفة تتراوح أعمارهن بـين 20 إلى 25 سنة.

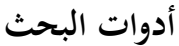

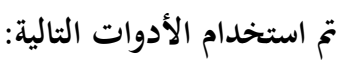

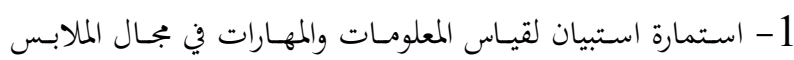

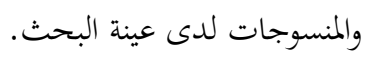

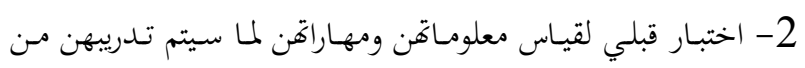

خامات وأدوات وتنفيذ.

3- برنامج تدريبي يهدف لتعلم المبحوثات أنواع الخامات والأدوات

المستخدمة والمهارات المختلفة.

4- اختبار معرفي بعدي لقياس مدى التحصيل.

5- اختبار مهاري لقياس مدى إلمامهن بالمهارات التي تم التدريب عليها.

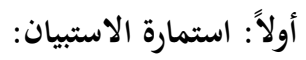

تم وضع استمارة استبيان تضم معارف ومعلومات عينة البحث

$$
\text { وقد تضمنت الاستمارة بجموعة من المحاور: }
$$

1- الخامات النسيجية وكيفية التمييز بينهم.

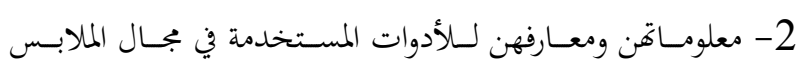

$$
\text { والمنسوجات. }
$$

3- المهارات التي يجيدها المعاق في مجال الملابس والنسيج والأشغال

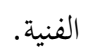

تم عرض الاستبيان على عدد من المتخصصين في مجالات الإعاقة

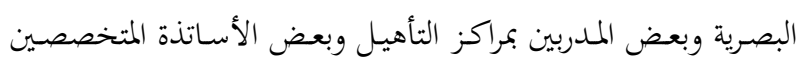
في مجال الملابس والمنسوجات وطبقاً لآراء المحكمين فقد تم الآني:

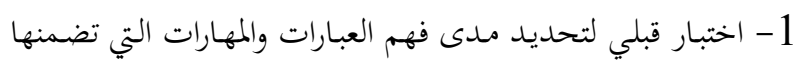

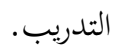

2- بطاقة تقييم للمهارات اليدوية وقد تم تحديدها بالآني (تراكيب

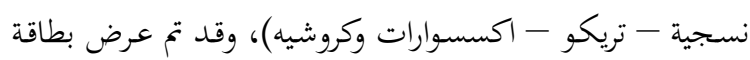

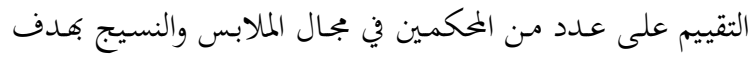

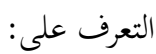
مدى مناسبة المهارات الملبسية للمكفوفات.
جما كل فرد منهم وتشمل المعوقين، الموهوبين، المرضى، الحوامل، والمسنين.

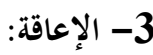

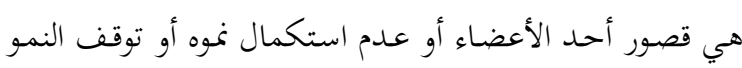

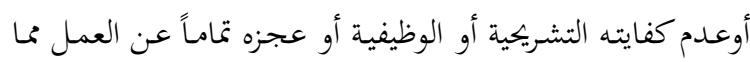

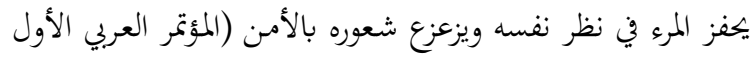

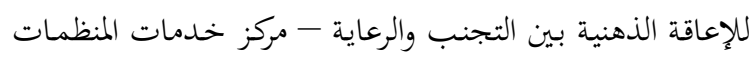
غير الحكومية - 13 - 14 يناير 2004 الإعالة الذنية بين الجنبية

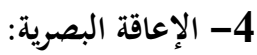

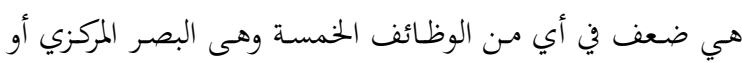
البصر الميطي أو التكييف البصري والبعد الثنائي ورؤية الألوان الثران الثيان

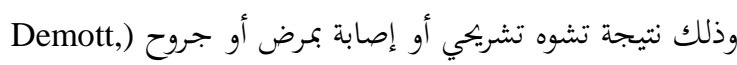

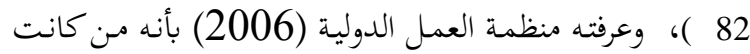

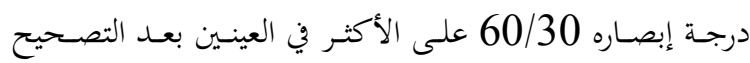

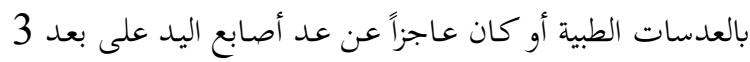
أمتار، ومن كان بجال بصره لا يزيد عن 20 درجة.

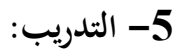

هو منظومة من التعليم المخطط الذي يساعد المتدربين في الحصول

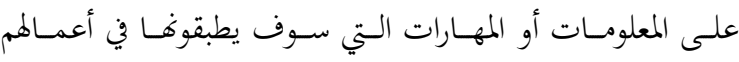
وبجتمعاتم (Wegs, 2003) والتدريب يزيد من معرفة المتدربين حول بجالات معينة وتغيير اتجاهاقم.

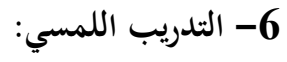

التدريب اللمسي هو تدريب المعاق على إدراك الأشكال والأشياء

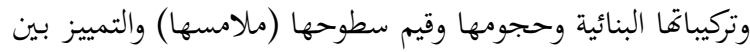

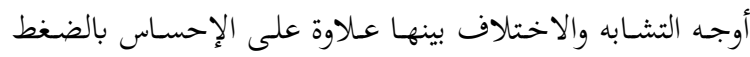
والحرارة عن طريق اللمس. (منتديات متحدي الإعاقة، 2007)

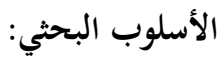

الشاملة: الأفراد ذوي الإعاقات من المكفوفات وذلك بدار الرسالة

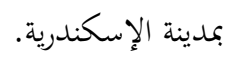

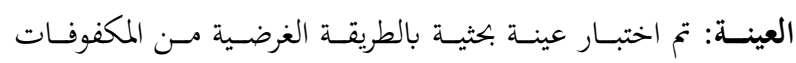

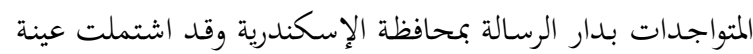


تم وضع المصطلحات للاستبيان التي تشير إلى المهارات المختلفة

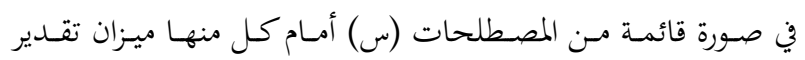

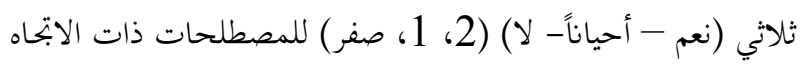
الموجب والعكس (صفر، 1، 2) للعبارات ذات الاتحاه السالب.

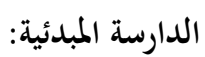
طبـق هـذا البحـث على عينـة عشـوائية مـن المشـرفين والمــدبين

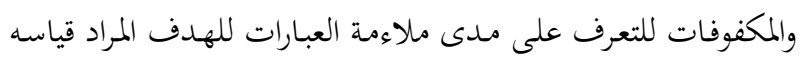
ومدى وضوح المصطلحات وقد أسفرت النتائج عن وضوح العبارات والتعليمات وطريقة رصد الدرجات.

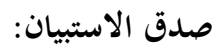
تم حساب صدق الاستبيان عن طريق عرض استمارة الاستبيان

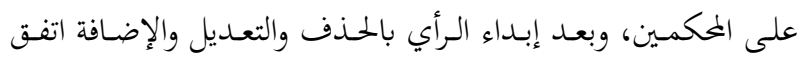

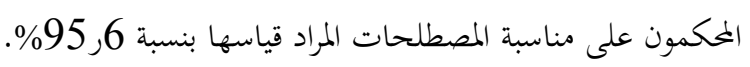

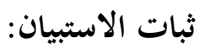
تم حساب ثبات الاستبيان عن طريق تطبيق استبيان مبدئي لعينة عشوائية (25) من المكفوفات والمشرفات ثم أعيد التطبيق مرة أخرى تبرى على نفس العينة بفاصل زمني أسبوعين وبحساب معامل ارتباط بين

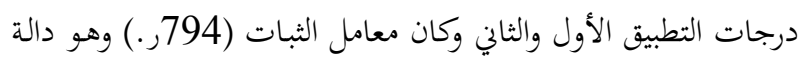

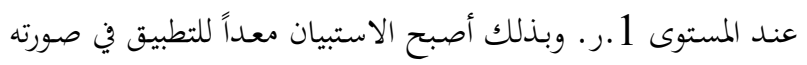
النهائية. ويوضح جدول (1) المهارات المختلفة والاختبارات الخاصة بما:
مدى مناسبة المهارات الملبسية المعرفية. مدى مناسبة المهارات الملبسية اللغوية. وبعـد العـرض على المحكمـين وإجـراء الحـذف والتعـديل والإضـافة

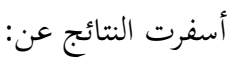

إلغـاء بعـض المهـارات اليدويسة لصعوبتها وعـدم ملاعمتهـا لنسوع الإعاقة مثل الكروشيه للمكفوفات. تعديل الاختبارات التي تقيس المعارف. إلغاء بعض الاختبارات التي تقيس المهارات اللغوية. إضافة بعض المهارات اللغوية للاختبار.

إضـافة بعـض المعـارف الخاصـة بالأدوات المسـتخدمة في جــال الملابس والنسيج والأشغال الفنية. وقد استقر الاستبيان على ججموعة من المهارات من أهمها: 1 - عبارات معرفية تعبر عن قدرة الملكفوفات على الإلمام بالمعلومات والمعارف.

2- معلومات لغوية لمعرفة أنواع الخيوط والأقمشة والاكسسوارات. 3- مهارات يدوية عن التراكيب النسجية. 4- مهارات اقتصادية تعبر عن قدرة المكفوفات على التعامل المادي والبيع والشراء وحساب التكلفة.

جدول 1. المهارات المختلفة والاختبارات ووحدة القياس الخاصة بما

\begin{tabular}{|c|c|c|}
\hline وحدة القياس & الاختبار & المهارة \\
\hline تعرف، لا تعرف، تعرف إلى حد ما & صناعية) العينـات على الطالبـات (قطن، صـوف، أليـاف & معرفية خاصة بالخامات \\
\hline & 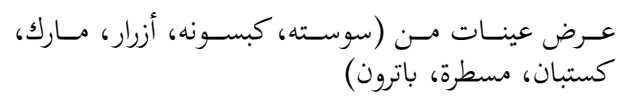 & الملابس والأشيـة خاصـــة بالأدوات المســتخدمة في مجـــال \\
\hline & أسئلة في بحال الملابس والنسيج & 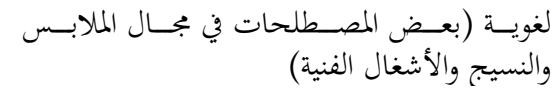 \\
\hline الزمن / الدقيقة & 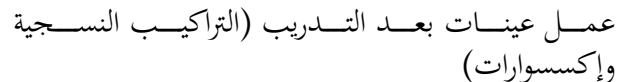 & يلدوية \\
\hline
\end{tabular}




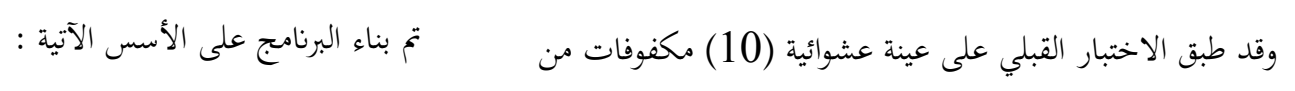

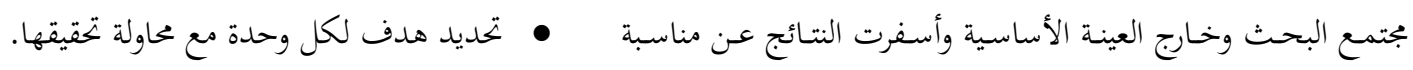

توفير بيئة مليئة بالمثيرات السمعية واللمسية واستخدامها بأسلوب الاختبار لقدرات المكفوفات.

جيد يتناسب وعينة البحث من حيث النوع والشكل والحجم.

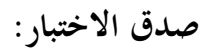

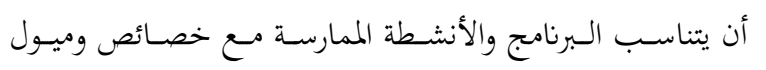

$$
\text { وقدرات المكفوفات. }
$$

وذلك عن طريق الصدق الظاهري حيث اتفق الخبراء على مناسبة

تلك القدرات لقياس ما وضعت من أجله ومناسبتها لعينة البحث.

مراعاة التنوع في طرق التدريس والأدوات والوسائل المستخدمة في

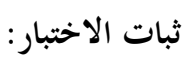

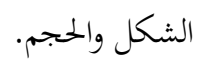

هالاستفادة من المواد المتاحة والمتوفرة في البيئة.

مراعاة الظروف النفسية والاجتماعية والصحية للمكفوفات وخلق

روح الصداقة بين الباحث والمكفوفات وتشجيعهم على الاستمرار

في بذل المجهود.

• مراعاة الفروق الفردية بين المكفوفات.

أن يتسم البرنامج بالمرونة حيث يسمح بإدخال التعديلات إذا لزم

مراعاة التدرج بالمهارات من السهل إلي الصعب.

يجب استعمال النموذج الجيد لأداء المهارات المختلفة نظراً لأفهم

$$
\text { يتعلموا من خلال التقليد للمعلم. }
$$

الأدوات المستخدمة في تنفيذ البرنامج :

$$
\text { أقمشة (قطن ، صوف ، نايلون). }
$$

تم حساب ثبات الاختبار عن طريق إعادة التطبيق على (10)

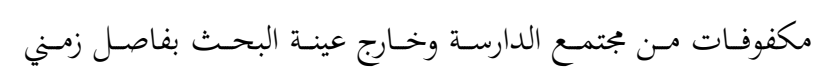

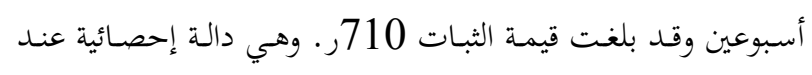

مستوى 01ر.

\section{ثانياً: البرنامج تدريبي لبعض المهارات في مجال الملابس والنسيج}

تم وضـع بـرنامج تـدربي لتنميـة مهارات عينـة البحـث في مجـال

$$
\text { الملابس والنسيج والأشغال الفنية وتشمل الآتي : }
$$

1 - تراكيب نسجية بخيوط ناعمة (أحمر / أزرق) وخيوط خشنة (ذهبي

وفضي) حتى يستطيع المكفوف استخدام حاسة اللمس. (مفارش

$$
\begin{aligned}
& \text { - معلقات - سبت تليفون) } \\
& \text { 2- 2 - كروشيه. } \\
& \text { 3- إكسسوارات بعجينة السيراميك. } \\
& \text { المدف من البرنامج : }
\end{aligned}
$$

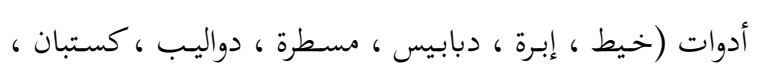

$$
\text { إبرة ، كروشيه ، إبرة تريكو). }
$$

خيوط (خيط ماكينة ، خيط صوف ، خيط قطن).

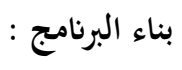

تم اختبار وتحديد محتوى البرنامج في ضوء مجموعة من الاعتبارات

$$
\text { والتي تتمثل في الأتي: }
$$

1

$$
\text { المكفوفات. }
$$

2- الاطلاع على الدراسات السابقة التي تمت في مجال المكفوفات

$$
\text { بصرياً. }
$$

يهدف البرنامج إلى إكساب المكفوفات بعض المهارات في مجال الملابس والنسيج والتي تؤهلهن للأداء الوظيفي المستقل في هذا المجال في حدود قدراقم مما يزيد من شعورهم بالرضا عن النفس وعن الآخرين منا يساعد على : 1 2 3 4

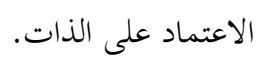

أسس وضع البرنامج : 


$$
\begin{aligned}
& \text { •لتشجيع المعنوي دور مهم في نجاح البرنامج. } \\
& \text { تم تحديد الفترات الزمنية لمكونات وحدات البرنامج. } \\
& \text { مناسبة الأدوات المستخدمة في تنفيذ البرنامج. }
\end{aligned}
$$$$
\text { 3- مقابلة شخصية مع خبراء في مجال المكفوفات (بصريا). }
$$$$
\text { وفي ضوء ما سبق وتبعاً للملاحظات التي أبداها الخبراء تم وضع }
$$$$
\text { البرنامج موضوع الدراسة }
$$

إلغاء بعض المهارات اليدوية لصعوبتها وعدم ملائمتها لنوع الإعاقة مثل

$$
\begin{aligned}
& \text { الكروشيه (للمكفوفات). } \\
& \text { الإجراءات والتطبيق : }
\end{aligned}
$$
عينة البحث الأساسية لمدة (12) أسبوع بواقع وحدة كل 3 أسابيع

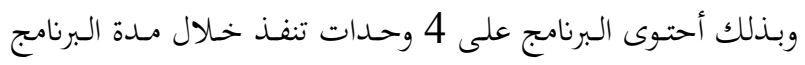

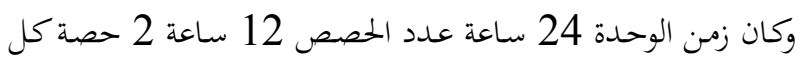
أسبوع زمن الحصة 2 ساعة.

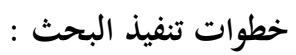

تم التطبيـق القبلـي للاستبيان الخـاص بالمهارات المختلفـة وذلكك

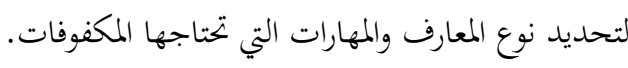
تم تنفيذ البرنامج التدريبي الإرشادي على أفراد العينة وذلك بدار

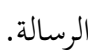
تم التطبيق البعدي للاستبيان الخاص بالمهارات المختلفة. تم تصحيح الاستجابات وجدولة الدرجات تمهيـاً لاستخلاص

$$
\text { النتائج ومناقشتها. }
$$

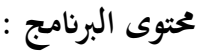

بالرجوع إلى نتائج الاستبيان الخاص بالمكفوفات بصرياً ملحق رقم (1) فقد تم حصر الأنشطة التي تنظمها تلك المهارات في إطار عام بـام

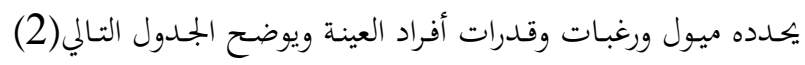
توزيع محتوى البرنامج التعليمي الإرشادي الدراسة الاستطلاعية للبرنامج :

قـام البـاحثون بدراسـة استطلاعية على عينـة قوامها (10) مـن

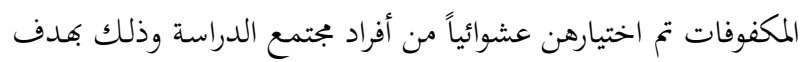

الوقوف على أنسب الطرق والوسائل التي تتلائم مع المكفوفات. تحديد الأسلوب التنظيمي للعمل وذلك للتأكد مـن توافر الأمسن والسلامة. تحديد الفترة الزمنية اللازمة لاتمام القياسات وتنفيذ البرنامج. تدريب المساعدين على تنفيذ البرنامج. وقد أسفرت نتائج الدراسة الأستطلاعية
بعد التأكد من صلاحية البرنامج للتطبيق تم تنفيذ البرنامج على مناسبة محتوى البرنامج للمكفوفات قيد البحث. التدريب على الوحدة لمدة أسبوعين. جدول 2. ت توزيع محتوى البرنامج

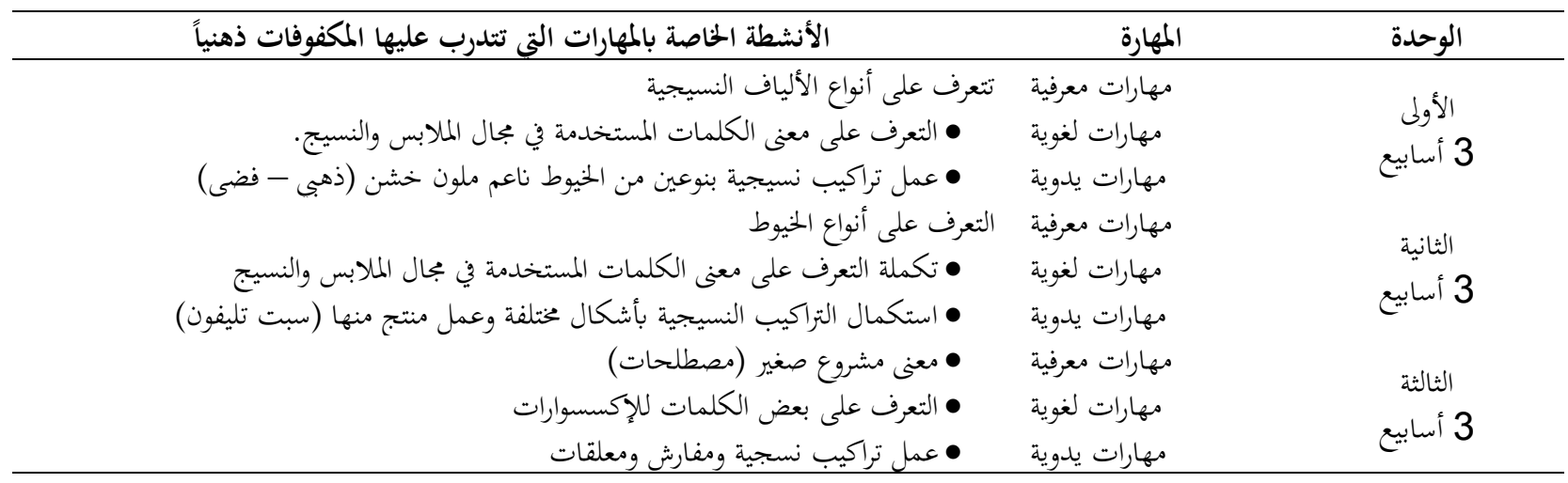


2- المهارات التي يستخدمها الكفيفات في مجال الملابس والنسيج

والأشغال الفنية

تم دراسـة مـدى إلمـام المككفوفـات بالمهـارات المختلفــة في مجـال

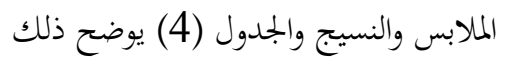

جدول 4. معلومات المعاق عن مهارات الملابس والنسيج

\begin{tabular}{|c|c|c|c|c|}
\hline \multicolumn{2}{|c|}{ ليس لديهن معلومات } & \multicolumn{2}{|c|}{ لديهن معلومات } & \multirow[b]{2}{*}{ البيان } \\
\hline$\%$ & العدد العد & $\%$ & العدد & \\
\hline$\% 11$ & 5 & $\% 88,89$ & 40 & 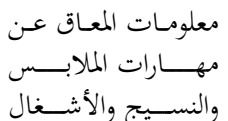 \\
\hline
\end{tabular}

يتضـح مـن الجـدول السـابق أن 89,88\% مـن المعـاقين لـديهم

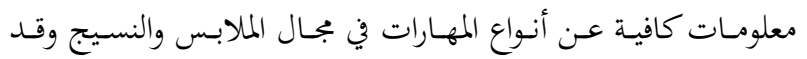

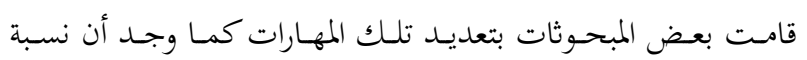

11 ليس للديهن معلومات عن تلك المهارات وهي نسبة ضئيلة

مقارنة بالنسبة التي تعرفن تلك المهارات.

ثانياً : نوع المهارات التي تم التدريب عليها :

تم تحديد أنواع المهارات التي تجيدها عينة البحث وذلك لتحديد

نوع المهارات التي سـوف تقـوم الباحثـة بتـدريب المبحـوثات عليها

وجدول (5) يوضح أنواع المهارات.

من الجدول (5) يتضح أن أكثر المهارات إجادة لدى الكفيفات الكهات

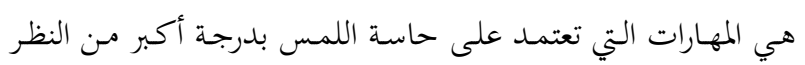

وهي عمل إكسسوارات في شكل (عقد ، إسورة) مـ الخـرز يعتمـد

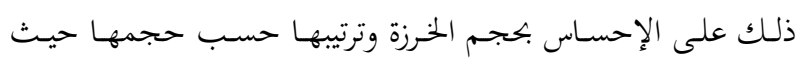

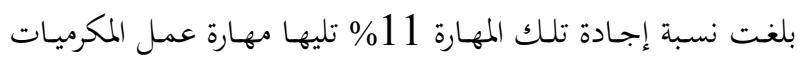

حيث بلغت نسبة الإجادة 22\% وهي تعتمد على الإحساس بسمك

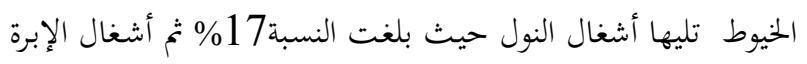

$$
\text { وبلغت نسبتها 11\% ثخم الكروشيه }
$$

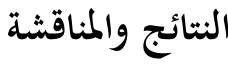

سوف تعرض النتائج التي تم التوصل إليها من خلال الأساليب

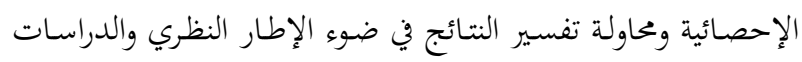

السابقة.

تم تطبيق الاستبيان وتفريغه وتحديد نتائج تطبيق البرنامج وكانت

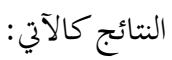

أولاً: نتـائج الاسـتبيان والـتي كــدف إلى تحديـد معــــ ومهـارات

المكفوفات

1- الخصائص الديموجرافية للمكفوفات عينة البحث :

الجــدول (3) يوضـح الخصـائص الديموجرافيسة للمكفوفـات عينـة

البحـث والـتي تتضـمن كـل مسن السـن والحالـة الاجتماعيسة ومكـان

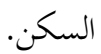

\begin{tabular}{|c|c|c|}
\hline النسبة المئوية \% & العدد & الخصائص \\
\hline$\% 43.7$ & 21 & السن 12 - 15 \\
\hline$\% 31,1$ & 14 & $18-15$ \\
\hline$\% 8,9$ & 4 & $21-18$ \\
\hline$\% 13,3$ & 6 & أكبر من 21 \\
\hline$\% 100$ & 45 & الججموع \\
\hline & & الحالة الاجتماعية \\
\hline$\% 91$ & 41 & عزب \\
\hline \multirow[t]{2}{*}{$\% 9$} & 4 & متزوج \\
\hline & & مكان الإقامة \\
\hline$\% 100$ & 45 & داخل الإسكندرية \\
\hline-- & -- & خارج الإسكندرية \\
\hline
\end{tabular}

جدول3. الخصائص الديموجرافية للمبحوثات

يتضح من جدول (3) أن 47\% من العينة تتراوح أعمارهن بين

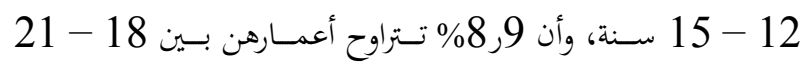

سنة، كما اتتضح أن 91\% من العينة غير متزوجات

\begin{tabular}{|c|c|c|c|c|c|c|c|c|c|c|c|c|c|c|c|c|}
\hline \multicolumn{2}{|c|}{ نول } & \multicolumn{2}{|c|}{ مكرميات } & \multicolumn{2}{|c|}{ إكسسوارات } & \multicolumn{2}{|c|}{ حياكة } & \multicolumn{2}{|c|}{ كروشيه } & \multicolumn{2}{|c|}{ تريكو } & \multicolumn{2}{|c|}{ عمل أبليك } & \multicolumn{2}{|c|}{ أشغال الإبرة } & \multirow{2}{*}{ نوع المهارة } \\
\hline$\%$ & العدد & $\%$ & العدد & $\%$ & العدد & $\%$ & العدد & $\%$ & العدد & $\%$ & العدد & $\%$ & العدد & $\%$ & العدد & \\
\hline 17 & 8 & 22 & 10 & 31 & 14 & - & - & 4 & 2 & 2 & 1 & - & - & 11 & 5 & العدد (\%) \\
\hline
\end{tabular}

جدول 5. أنواع المهارات التي تجيدها المبحوثات 


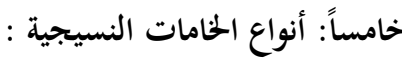

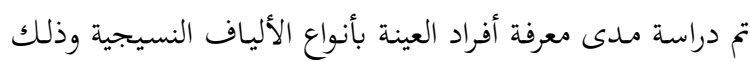

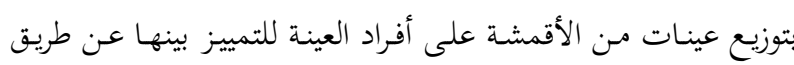

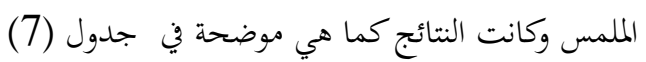

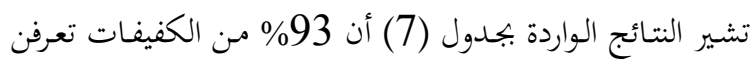

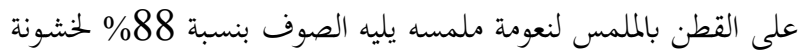

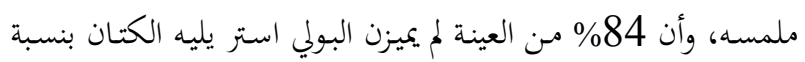

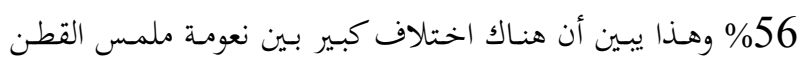

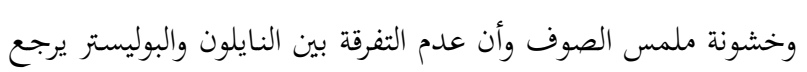

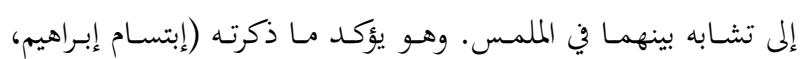
2003) أن 40\% مـ حجم عينة المكفوفات تعتمد على الأسرة

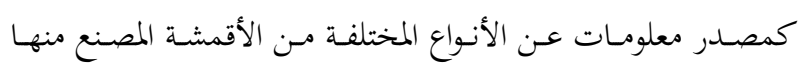
الملابس. - إس.

سادساً: الأدوات المستخدمة في مجال الملابس والنسيج :

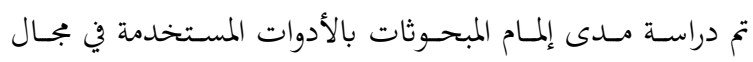

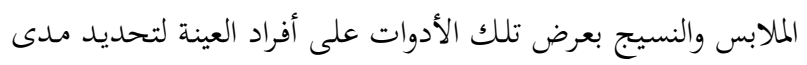
معرفتهم بتلك الأدوات وجدول (8) يوضح ذلك.
بنسبة 4\% أما مهارة الحياكة وعمل الأبليك فلم تجيدها أي من أفراد

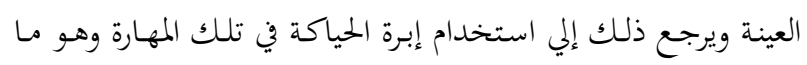

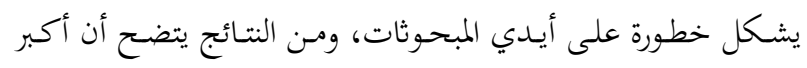

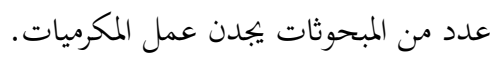
ثالثاً: مصادر تعلم تلك المهارات : وبدراسة مصادر تعلم الكفيفات للمهارات المختلفة والمتمثلة في الأم ، أحد أفراد الأسرة الأصدقاء المركز التعليمي أحد مراكز الحدمة الحسات

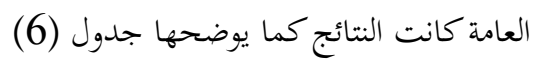

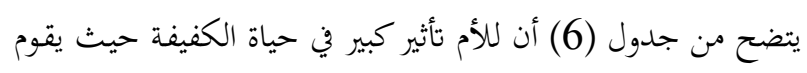

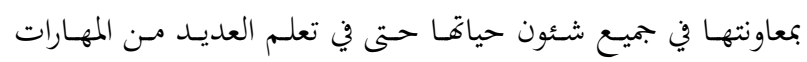
حيث بلغت نسبة تعلم المهارات من الأم 38 \% يليها أحسا كند أفراد

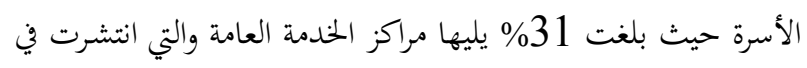

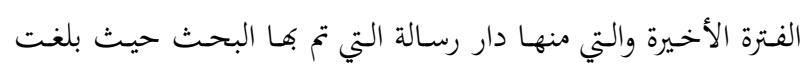

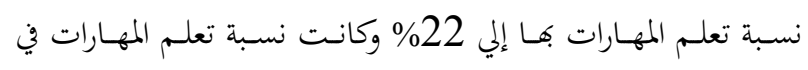
المراكز التعليمية أقل نسبة حيث بلغت

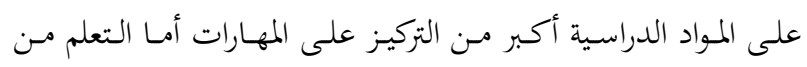

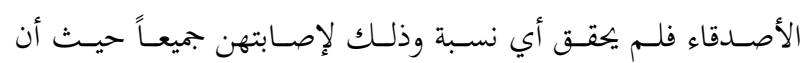
الأصدقاء هم أصدقاء الدراسة والمدرسة.

جدول 6. مصادر تعلم تلك المهارات

\begin{tabular}{|c|c|c|c|c|c|c|c|c|c|c|}
\hline \multicolumn{2}{|c|}{ مراكز الحخدمة العامة } & \multicolumn{2}{|c|}{ المركز التعليمي } & \multicolumn{2}{|c|}{ الأصدقاء } & \multicolumn{2}{|c|}{ أحد أفراد الأسرة } & \multicolumn{2}{|c|}{ الأم } & \multirow{2}{*}{ مصادر تعلم المهارات المجلات } \\
\hline$\%$ & عدد عد ال & $\%$ & عدد & $\%$ & عدد ع & $\%$ & عدد & $\%$ & عدد & \\
\hline 22 & 10 & 8,9 & 4 & -- & -- & 31 & 14 & 38 & 17 & تعلم المهارات المختلفة \\
\hline
\end{tabular}
جدول 7. توزيع المبحوثين طبقا لمعرفة أنواع الأليافة

\begin{tabular}{|c|c|c|c|c|}
\hline \multicolumn{2}{|c|}{ ل ل ايميز } & \multicolumn{2}{|c|}{ يميز } & \multirow{2}{*}{ البيان } \\
\hline$\%$ & العدد العد & $\%$ & 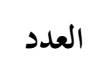 & \\
\hline 7 & 3 & 93 & 42 & ملمس متوسط النعومة \\
\hline 11 & 5 & 88 & 40 & ملمس خشن (صوف) \\
\hline 29 & 13 & 71 & 32 & ملمس شديد النعومة (نايلون) \\
\hline 56 & 25 & 22 & 20 & أسمك من القطن (كتان) \\
\hline 84 & 38 & 16 & 7 & أقل نعومة من النايلون (بولي ستر) \\
\hline
\end{tabular}


جدول 8. مدى إلمام المبحوثات بالأدوات المستخدمة

\begin{tabular}{|c|c|c|c|c|c|c|}
\hline \multicolumn{2}{|c|}{ لا يعرف } & \multicolumn{2}{|c|}{ يعرف إلى حد ما } & \multicolumn{2}{|c|}{ يعرف } & \multirow{2}{*}{ 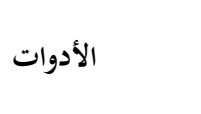 } \\
\hline$\%$ & العدد & $\%$ & العدد & $\%$ & العدد & \\
\hline-- & -- & -- & -- & 100 & 45 & إبرة حياكة \\
\hline-- & -- & -- & -- & -- & 42 & خيط حياكة \\
\hline 29 & 13 & 11 & 5 & 60 & 27 & خيط تريكو \\
\hline-- & -- & -- & -- & 100 & 45 & مسطرة \\
\hline-- & -- & 9 & 4 & 91 & 41 & دبابيس \\
\hline 89 & 40 & 11 & 5 & -- & -- & كربون \\
\hline 100 & 45 & -- & -- & & & كستبان \\
\hline 100 & 45 & -- & -- & & & روليت \\
\hline 100 & 45 & -- & -- & & & مارك \\
\hline 100 & 45 & -- & -- & & & باترون \\
\hline
\end{tabular}

جدول 9. إلمام المبحوثات ببعض المصطلحات في مجال الملابس

\begin{tabular}{|c|c|c|c|c|c|c|}
\hline \multicolumn{2}{|c|}{ لا يعرف } & \multicolumn{2}{|c|}{ يعرف إلى حد ما } & \multicolumn{2}{|c|}{ يعرف } & \multirow{2}{*}{ المصطلحات } \\
\hline$\%$ & العدد & $\%$ & العدد العد & $\%$ & العدد & \\
\hline 67 & 30 & 11 & 5 & 22 & 10 & نسيج \\
\hline 78 & 35 & 6 & 3 & 15 & 7 & تريكو يدوي \\
\hline 80 & 36 & 19,56 & 7 & 4,4 & 2 & تريكو آلي \\
\hline \multirow{7}{*}{99,56} & 43 & - & & 4,4 & 2 & كروشيه \\
\hline & -- & 11 & 5 & 89 & 40 & مريلة مطبخ \\
\hline & & - & & 100 & 45 & فستان \\
\hline & & - & & 100 & 45 & بنطلون \\
\hline & & - & & 100 & 45 & قميص \\
\hline & & - & & 100 & 45 & شراب \\
\hline & -- & 33 & 15 & 67 & 30 & إيشارب \\
\hline 4,4 & 2 & 22 & 10 & 73 & 33 & ملابس صيفية \\
\hline 6,44 & 3 & 11 & 5 & 82 & 37 & ملابس شتوية \\
\hline
\end{tabular}

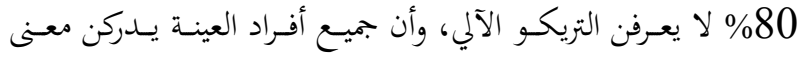

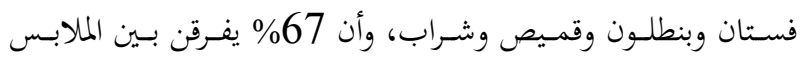

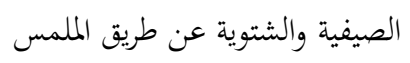
الإكسسوارات :

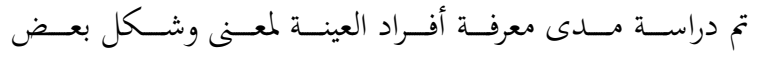
الإكسسوارات الخاصة بمجال الملابس والنسيج والجمدول التالي (10)

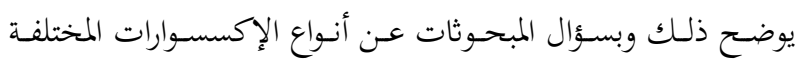
المستخدمة في الملابس اتضح أن 6509 95 يعرفن الأزرار،
يتضح من الجمدول أن جميع المبحوثات يعرفن إبرة الحياكة، واستطعن

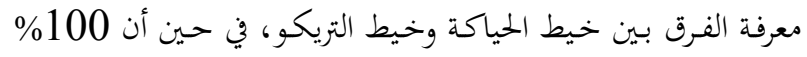
من العينة لا يعرفن الكستبان والروليت والمارك وما هو الباترون. مصطلحات في مجال الملابس : تم دراسـة مــدى إلمـام المبحــوثين بسبعض المصـطلحات في مجـال الملابس كانت النتائج كما يوضحها جدول(9) أظهرت نتائج جدول

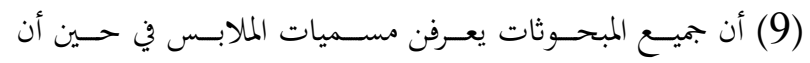
\%99,56 لا يعرفن الكروشيه، 
• قَدف هذه الدراسة إلي تنمية قدرات المكفوفات وتعريفهم ببعض الأعمال اليدوية والتي تساعدهم على تحصيلهم المهني وتملكهم من

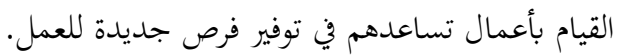

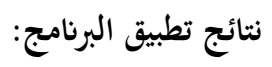

يستتعرض النتـائج الخاصـة بالاختبـار التحصسيلي والمهاري وهي

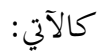

حساب فاعلية وصدق ثبات الاختبار المهاري والتحصيلي للعينة

الاستطلاعية

أولاً: نتـائج فاعليـة الاختبـار التحصسيلي المعـرفي القبلـي والبعـدي

للعينة الاستطلاعية

ثانياً: نتائج حساب الثبات والصدق الذاتي للاختبار.
كما أن جميع أفراد العينة يعرفن الحزام أهمية تعلم بعض المهارات :

تم دراسة مـدى أهمية تعلم بعض المهارات بالنسبة لأفراد العينة

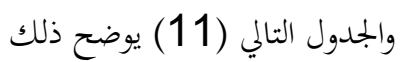

يتضح من جدول (11) أن 55,55\% م5 بيديدن بعض المهارات

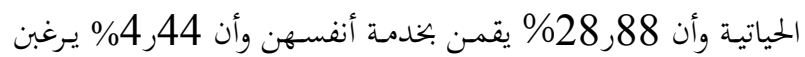

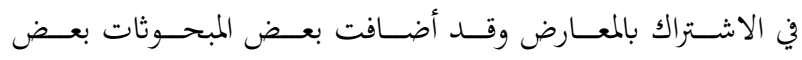

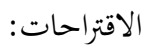

• منها استخدامها كهدايا، استخدامها في المنزل.

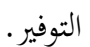

برنامج تدريبي لتنمية مهارات المكفوفات في بجال الملابس والنسيج

جدول10. معرفة معنى وشكل بعض الإكسسوارات

\begin{tabular}{|c|c|c|c|c|c|c|}
\hline \multicolumn{2}{|c|}{ لا يعرف } & \multicolumn{2}{|c|}{ يعرف إلى حد ما } & \multicolumn{2}{|c|}{ يعرف } & \multirow{2}{*}{ الإكسسوارات } \\
\hline$\%$ & العدد & $\%$ & 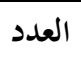 & $\%$ & 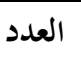 & \\
\hline & & 4,4 & 2 & 95,6 & & ز ز \\
\hline- & -- & 2 & 1 & טקנת & 43 & كبسولة \\
\hline 60 & 27 & 13 & $\begin{array}{l}1 \\
6\end{array}$ & $\begin{array}{l}50 \\
6.44\end{array}$ & 17 & عروة \\
\hline 80 & 36 & 10 & & 4 & 3 & \\
\hline- & -- & 267 & -- & 100 & 45 & حزام \\
\hline 20 & 9 & 26,7 & 12 & 53,3 & 24 & سوسته \\
\hline 93 & 42 & - & -- & 6,44 & 3 & أبليك \\
\hline 77 & 35 & - & -- & 22 & 10 & تطريز \\
\hline 38 & 17 & - & -- & 62 & 28 & \\
\hline 76 & 34 & 6,44 & 3 & 17,6 & 8 & 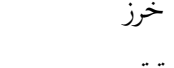 \\
\hline
\end{tabular}

جدول 11. مدى أهمية تعلم مهارة بالنسبة لأفراد العينة

\begin{tabular}{|c|c|c|}
\hline 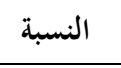 & 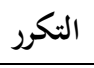 & نوع المهارة \\
\hline 55,55 & 25 & 1 - 1 - إجادة بعض المهارات الحياتية \\
\hline 28,88 & 13 & 2 - خدمة نفسها بنفسها \\
\hline 26,66 & $\begin{array}{c}12 \\
5\end{array}$ & 3 - شغل وقت الفراغ \\
\hline 11,11 & 2 & 4 - وسيلة للكسب من خلال مشروع صغير \\
\hline 4,44 & 2 & 5 - الاشتراك في المعارض \\
\hline 4,44 & & 6 - تحدي الإعاقة وإثبات الذات \\
\hline
\end{tabular}


ذلك يتضح من جدول (13) وجود فروق شديدة المعنوية بين زمن

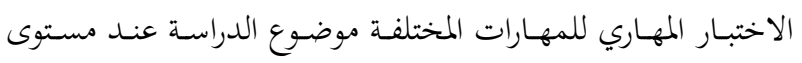
معنوية 01ر الختبار المري يستعرض جدول رقم (14) قيم متوسط درجات الاختبار المعرفي

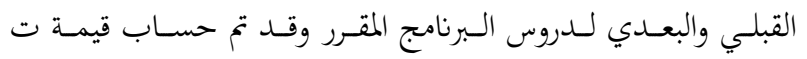

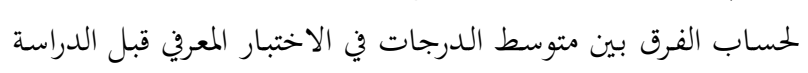
يتضح من جدول (14) فروق ذات دلالة إحصائية عند مستوى معنويسة 01010 بـين متوسط درجـات الاختبـار المهـاري للمهـارات المختلفة موضوع الدراسة. يستعرض جـدول (15) قيم متوسط درجـات الاختبـار المعـريف

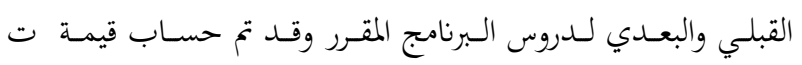

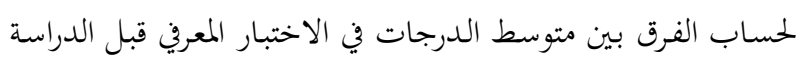

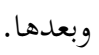

ثالثاً: نتائج حساب الفـرق بين درجات الاختبار التحصيلي القبلي والبعدي الفوري والبعدي المرجأ للعينة الاستطلاعية. رابعاً: نتائج فاعلية الاختبار المهاري لدروس البرنامج فاعلية الاختبار القبلي والبعدي للعينة المبدئية: تم تقـــير فاعليـة الـبرنامج بحســاب قيمسة متوسـطات درجــات الاختبار المعرفي للعينة المبدئية القبلي والبعدي الفوري والبعدي المرجأ

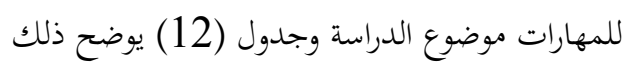
يتضح من الجدول وجود فروق شديدة المعنوية عند مستوى معنوية

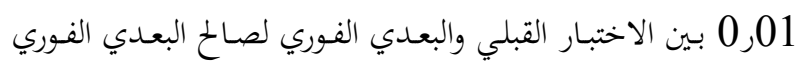
وهذا يدل على كفاءة البرنامج التدريبي. مقارنة بين زمن الاختبار المهاري للدروس المختلفة عن طريق تحليل التباين: تم مقارنة بين زمن الاختبار المهاري للدروس مجتمعة عن طريق تحليل التباين ANOVA وذلك للمهارات الستة، والجدول رقم (13) يوضح

جدول 12. مقارنة بين متوسطات درجات الاختبار المعرفي للعينة المبدئية

\begin{tabular}{|c|c|c|c|c|}
\hline الإكسسوارات المختلفة & الأدوات المختلفة & المصطلحات المستخدمة في الملابس والنسيج & الخامات النسيجية & المهارة المعرفية \\
\hline 83 & 32 & 60 & 50 & 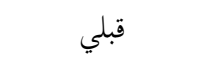 \\
\hline 95 & 72 & 92 & 59 & بعدي فوري \\
\hline 81 & 60 & 83 & 80 & بعدي مرجأ \\
\hline 86 & 54 & 78 & 63 & 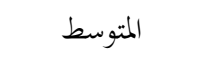 \\
\hline$* *$ & $* *$ & $* *$ & $* *$ & أقل فرق معنوي \\
\hline 0,49 & 0,44 & 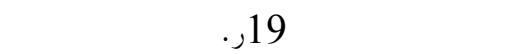 & 1,44 & معامل الاختلاف \\
\hline
\end{tabular}

جدول 13. تحليل التباين لزمن الاختبار المهاري القبلي والبعدي للعينة المبدئية للمهارت متوسط مربع الانحرافات

\begin{tabular}{|c|c|c|c|c|c|c|c|}
\hline علبوط مناديل & مفرش باستخدام & مفرش بخيوط & معلقة حائط & عمل سبت & إكسسوارات & درجات & 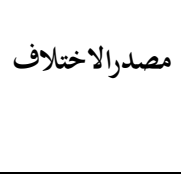 \\
\hline ***211,72 & ***314,58 & *** 243,99 & ***4 445,18 & ***3 348,81 & *** 59,74 & 2 & بين المعاملات \\
\hline ,002 & 001 & 002 & 001 & 001 & 007 & 6 & الخطأ التجريبي \\
\hline \multicolumn{8}{|c|}{ 0,01" تشير إلى فروق عالية المعنوية عند مستوى معنوية } \\
\hline
\end{tabular}


جدول 14. مقارنة بين متوسط درجات الاختبار المهاري القبلي والبعدي الفوري والبعدي المرجأ للعينة المبدئية

\begin{tabular}{|c|c|c|c|c|c|c|}
\hline \multicolumn{6}{|c|}{ المهارات المختلفة } & \multirow{4}{*}{ المهارات } \\
\hline \multirow{3}{*}{ علبوط اللاسيه } & مفرش باستخدام & & & & إكسسوارات & \\
\hline & التراكيب النسجية & مفرش بخيوط المكرمية & معلقة حائط & سبت تليفون & بعجينة & \\
\hline & (خيوط الساتان) & & & & السيراميك & \\
\hline صفر C & صفر C & صفر C & صفر C & صفر C & صفر C & 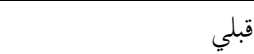 \\
\hline A 23,70 & B30,30 & B24,00 & B47,70 & B36,2 & B 59,7 & بعدي فوري \\
\hline B 22,7 & A 37,7 & A 28,7 & A 47,3 & A 38,7 & A 80 & بعدي (مرجأ) \\
\hline 15,8 & 22,00 & 17,57 & 31,67 & 24,97 & 46,57 & المتوسط العام مثل فرق \\
\hline **⿻丷木 & *** & *** & *** & *** & *** & معنوي \\
\hline 0,39 & 0,27 & 0,41 & 0,19 & 0,26 & 1,48 & معامل الاختلاف \\
\hline
\end{tabular}

هناك علاقة غير معنوية بين المعلومات عن الأدوات المستخدمةفي مجال النسيج قبل وبعد البرنامج.

\section{متوسط درجات الاختبار المهاري للعينة الأساسية:}

تم حساب قيم الاختبار المهاري للعينة الأساسية القبلي والبعدي

الفوري والبعدي المرجأ وجدول (18) يوضح نتائج هذا الاختبار.

يتضـح مـن الجـدول وجـود فـروق معنويـة بـين الاختبـار البعـدي

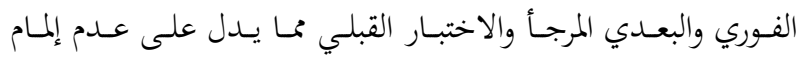
المكفوفات بأي مهارات قبل تطبيق الاختبار.

يوضـح جــدول (19) الخطأ التجـيبي ومصـدر الاخستلاف بـين المعـاملات للاختبـار المهاري القبلي والبعـدي الفوري والبعدي المرجـأ للعينة الأساسية.

يتضح من الجدول السابق وجود فروق شديدة المعنوية بين لجميع

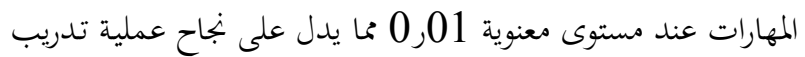
المكفوفات على إكتساب مهارات مختلفة دراسة الجدوى للمنتجات المنفذة: بعـد تنفيـذ المنتجـات التي قامـت بهـا المكفوفـات تم حسـاب التكلفـة الفعلية للمنتجات وعرضها للبيع من خلال المعرض المقام بمؤسسة دار رسالة والذي يقام بصورة دورية للمنتجات وتم حسـاب نسبة الربح حتى تشعر المكفوفة بالثقة بالنفس وأنه بإمكاهـا الاعتماد على ذاهـا وإيجاد فرص عمل لها وتصبح من متصدي الإعاقة،
من الجدول (15) يتضح وجود فروق ذات دالة إحصائية عند مستوى معنوية 01ر بين متوسط درجات الاختبار المعرفي قبل الدراسة وبعد الدراسة حيث بلغت قيمة ت في دروس الخامات النسجية المستخدمة 68,42 والمصـطلحات المستخدمة في الملابسس 90,00 والأدوات 24,00 بينما الإكسسوارات 00,52. تم تحليل التباين للاختبار المهاري القبلي والبعدي الفوري والبعدي

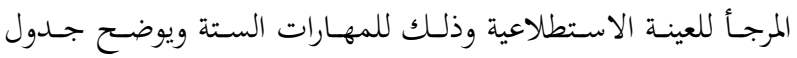
(16) ذلك من الجدول السابق يتضح أن هناك فروق شديدة المعنوية عند مستوى معنوية 0101 تقدير المتوسط العام لدرجات الاختبار المعرفي قبل وبعد الدراسة

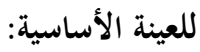
تم اسـتخدام إختبـار ت لحســاب الفـرق بـين متوسـي درجـات الاختبـار المعـرفي القبلـي والبعـدي للـبرنامج، ويوضسح جــدول (17) ذلك.

يتضح من الجمدول (17) وجهود فروق ذات دالة إحصائية بين

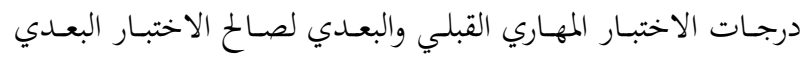
حيث بلغت قيمة ت 44,00 للخامات النسيجية المستخدمة بينما المعلومــات عـن الأدوات المســخدمة في ججــال النسـيج 89,89، والإكسسوارات المستخدمة 00,35 مما يدل على فاعلية البرنامج في زيادة القدرة المعرفية لدى المكفوفات في ججال الملابس والنسيج، بينما 
جدول15. متوسط درجات الاختبار المعرفي القبلي والبعدي (العينة الاستطلاعية)

\begin{tabular}{|c|c|c|c|c|c|c|c|c|}
\hline \multicolumn{8}{|c|}{ المعارف } & \multirow{3}{*}{ الإحصاء / المعارف } \\
\hline \multicolumn{2}{|c|}{ الإكسسوارات المستخدمة } & \multicolumn{2}{|c|}{ الأدوات المختلفة } & \multicolumn{2}{|c|}{ المصطلحات المستخدمة في } & \multicolumn{2}{|c|}{ الحمامات النسيجية } & \\
\hline بعدي & قبلي & بعدي & قبلي & بعدي & قبلي & بعدي & قبلي & \\
\hline 83,33 & 66,00 & 72 & 32 & 92,33 & 60,00 & 80,67 & 50,20 & المتوسط (ش) \\
\hline 2,33 & 1,00 & 4,00 & 4,00 & 2,33 & 4,00 & 4,33 & 1,75 & التباين (ق 2) \\
\hline 1,52 & 1,00 & 2,00 & 2,00 & 1,23 & 2,00 & 2,08 & 1,33 & الإخراف المعياري (ق) \\
\hline \multicolumn{2}{|c|}{$\begin{array}{c}52,00 \\
* *\end{array}$} & \multicolumn{2}{|c|}{$\begin{array}{c}24,00 \\
* *\end{array}$} & \multicolumn{2}{|c|}{$\begin{array}{l}97,00 \\
* *\end{array}$} & \multicolumn{2}{|c|}{$\begin{array}{l}68,42 \\
* *\end{array}$} & موبة معنوياً \\
\hline
\end{tabular}

جدول 16. تحليل التباين لزمن الاختبار المهاري القبلي والبعدي الفوري والبعدي المرجأ للعينة الاستطلاعية

\begin{tabular}{|c|c|c|c|c|c|c|c|}
\hline \multicolumn{6}{|c|}{ متوسط مربع الانحرافات } & \multirow[b]{2}{*}{ درجــــــات } & \multirow[b]{2}{*}{ مصدرالاختلاف } \\
\hline علبة مناديل & مفرش باستخدام & مفرش بخيوط & معلقة حائط & سبت تليفون & إكسسوارات & & \\
\hline ***3,991 & ***3,382 & ***3 3,194 & ***3,927 & ***4,934 & ${ }^{* * *} 4,647$ & 2 & بين المعاملات \\
\hline ,021 & ,034 & ,015 & ,049 & 030 & 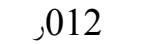 & 6 & الخطأ التجريي \\
\hline & & & & & عنوية 01ر & عنوية عند مستو & "** تشير إلى فروق . تشي \\
\hline
\end{tabular}

جدول 17. متوسط درجات الاختبار المعرفي القبلي والبعدي (العينة الأساسية)

\begin{tabular}{|c|c|c|c|c|c|c|c|c|}
\hline \multicolumn{8}{|c|}{ المعارف } & \multirow{3}{*}{ المعارف } \\
\hline \multicolumn{2}{|c|}{ الإكسسوارات المستخدمة } & \multicolumn{2}{|c|}{ المصطلحات المختلفة } & \multicolumn{2}{|c|}{ الأدوات المستخدمة في مجال } & \multicolumn{2}{|c|}{ الحخامات النسيجية } & \\
\hline بعدي & قبلى & بعدي & قبلى & بعدي & قبلى & بعدي & قبلى & \\
\hline 84,33 & 66,83 & 80,00 & 74,67 & 59,50 & 42,50 & 74,83 & 60,17 & المتوسط (ش) \\
\hline 2,33 & 0,58 & 34,72 & 2,33 & 3,25 & 1,75 & 1,58 & 3,08 & التباين (ق 2) \\
\hline 1,53 & 0,76 & 18,63 & 1,53 & 1,80 & 1,33 & 1,26 & 1,76 & الإنراف المعياري (ق) \\
\hline \multicolumn{2}{|c|}{35,00} & \multicolumn{2}{|c|}{00,54} & \multicolumn{2}{|c|}{58,89} & \multicolumn{2}{|c|}{$\begin{array}{l}44,00 \\
\text { *** }\end{array}$} & قيمة ت المحسوبة معنوياً \\
\hline & & & & & & عنوية 01 & عند ه & ** تشير إلى فروق عالية | تش \\
\hline
\end{tabular}

جدول 18. الاختبار المهاري القبلي والبعدي والبعدي المرجأ للعينة الأساسية

\begin{tabular}{|c|c|c|c|c|c|c|}
\hline \multicolumn{6}{|c|}{ المهارات المختلفة } & \multirow[b]{2}{*}{ المعاملة المهارات } \\
\hline علبة مناديل بخيوط & مفرش باستخدام & مفرش بخيوط المكرمية & معلقة حائط & سبت تليفون & إكسسوارات & \\
\hline صفر C & صفر C & صفر C & صفر C & صفر C & صفر C & قبلى \\
\hline B 7,00 & A 9,00 & A 6,17 & A 7,67 & A 8,17 & A 7,00 & بعدي فوري \\
\hline A 7,47 & В 4,67 & B 2,17 & В 6,00 & B 7 & В 6,17 & بعدي" (مرجأ) \\
\hline 4,82 & 4,56 & 2,78 & 4,56 & 5,06 & 4,39 & المتوسط العام مثل فرق \\
\hline *** & $* *$ & *** & **⿻丷木 & **⿻丷木 & **⿻丷木 & معنوي \\
\hline \multirow[t]{2}{*}{5,63} & 6,65 & 14,70 & 9,54 & 9,49 & 6,75 & معامل الاختلاف \\
\hline & & وجود فروق معنوية & ل غير المتشا & غير معنوية، & لهة تشير إل & المتوسطات ذات الحروف \\
\hline
\end{tabular}


جدول 19. تحليل التباين لزمن الاختبار المهاري القبلي والبعدي الفوري والبعدي المرجأ للعينة الأساسية

\begin{tabular}{|c|c|c|c|c|c|c|c|}
\hline \multicolumn{6}{|c|}{ متوسط مربع الانحرافات } & \multirow[b]{2}{*}{ درجات الحرية } & \multirow[b]{2}{*}{ مصدرالاختلاف } \\
\hline علبة مناديل & مفرش باستخدام & مفرش بخيوط & معلقة حائط & عمل سبت & $\begin{array}{c}\text { إكسوارات بعجينة } \\
\text { السيراميك }\end{array}$ & & \\
\hline **4 4,295 & $* * 4,362$ & *** 2,63 & $* * 4,028$ & $* * 4,55$ & ${ }^{* *} 3,82$ & 2 & بين المعاملات \\
\hline م & م & 057 & 038 & م & م & 6 & الخطأ التجريبي \\
\hline
\end{tabular}

جدول رقم 19. الجدوى الاقتصادية لمنتجات المكفوفات

\begin{tabular}{|c|c|c|c|}
\hline الربح بالجنيه & 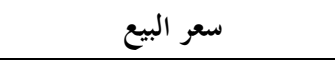 & النكلفة الفعلية & المنتج \\
\hline 13 & 25 جنيه (تم عمل 100دبوس) & عجينة السيراميك + دبابيس (8 جنيه) & إكسسوارات بينة السيراميك \\
\hline 5 & 20 & 15 & سبت تليفون \\
\hline 5 & 16,5 & 11,5 & معلقة الحائط \\
\hline 5 & 10 & 5 & مفرش بخيوط المكرمية \\
\hline 5 & 25 & 20 & مفرش باستخدام التراكيب النسجية (خيوط الساتان) \\
\hline 5 & 16 & 11 & علبة مناديل بخيوط اللاسيه \\
\hline
\end{tabular}

فاطمة مصطفى عبدالفتاح(2001)، فاعلية مواقف تعليمية مقترحة في

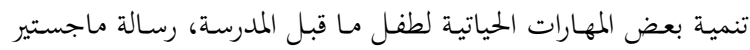

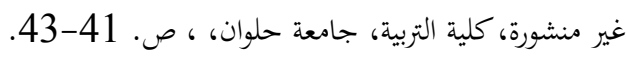

ماجدة مصطفى (1981) "دراسة مقترحة لتدريس الرسم للكفيفات

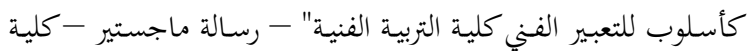

التربية الفنية - جامعة حلوان.

مركز المعلومات ودعم إتخاذ القرار (2005) - رئاسة مجلس الوزراء.

المؤتمر العربي الأول للإعاقة الذهنية بين التجنب والرعاية (2004) -

مركز خدمات المنظمات غير الحكومية - 13 - 14 يناير

\section{المراجع باللغة الإنجليزية:}

- Demott, R. (1982) "Visual Impairment" In N. Gharing (Ed.), Exceptional Children and Youth Colombus, Ohaio: Chavles E. Merrill

- Henger D.: Life Skills a cross, the curriculum combined teacher, student manual department of general academic education, country of publishing U.S., New Jersey; 1992. page 15-22.

- Jill Molloy (2003) "Effective Training in Reproductive Health", United States of America.

- Singorelli, V.A.: Daily Living and physical Education Skills for Elementary Mild Retarded
ويوضح الجدول (19) دراسة الجدوى الاقتصادية للمنتجات اليدوية

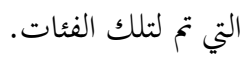

\section{التوصيـات}

تشجيع المكفوفـات على ممارسـة كافـة الأعمـال اليدويـة التي لا تحتاج إلى البصر في تنفيذها.

ضـرورة التعـاون بـين كافـة التخصصـات العلميـة والفنيـة لتحقيـق هدف النهوض بالمكفوفات لإعداد مواطن صالح.

رفع المعاناة عن المكفوفات وخلق كوادر مدربة منهم، وإتاحة فرص عمل جديدة تتناسب مع ظروفهم الصحية وتعاوغم على المنافسة

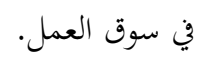

$$
\text { المراجع }
$$

إبتسام إبراهيم مُحَّم، (2003) "تنمية الوعي الملبسي للمكفوفين من خلال

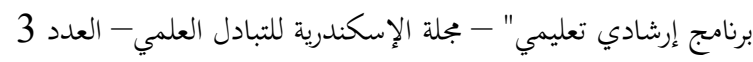
- مجلد 24. ص بر إرنادي تعليمي 323 إلى 340. عبدالمجيد عبدالرحيم (1988) "تنمية الأطفال المعوقين" - دار غريب للطباعة. 
واجتماعياً (2006/12/7) - شعبة التربية الخاصة - إدارة تعليم البنات

$$
\text { بجدة - دار الحياة }
$$

- www.montada9.com Bulletin v36.2. copy right 2000 -2007 ,

$$
\text { كيف تتطور الحواس للمعاق بصرياً }
$$

- www.cybrarians.info/journal/no9/software.htm.

فاطمة الزهراء يُحَّ عبده "برجيات المعاقين بصرياً واستخدامها في المكتبات
Pupils, Los Angelus City Schools, Instr4uctional Programs, Branch 1991, Page 327.

$$
\text { المراجع بالإنترنت: }
$$

- www.almaref.net/archive/index.nhn/t2007

$$
\text { تنمية إتحاهات المجتمع نخو المعاقين بصرياًشديد على دور الأسرة في }
$$

$$
\text { إحتضان المعوقين نفسيا }
$$


منا موسى غالب وأخرون : تنمية معارف ومهارات المكفوفات في مجال المنسوجات والملابس من خلال برنامج تدريبي

\title{
Developing Blind Females' Skills in the Field of Clothes and Textile Through a Training Program
}

\author{
Azza Ibrahim, Safia Sarokh and Anaam Abozeid
}

This study was conducted on a sample of 45 blind females at the age group from $12-24$ years who are affiliated to one of the institutions which cares for blinds, this institution namely Ressala Association, Alexandria. The study aims to train the blind females on some handmade works related to clothes and textile which help them acquire technical skills and enable them to practice work which provides them with an opportunity of new jobs in the field of clothes and textile.

The blind females were trained and gained different knowledge, handcraft, and economical skills in the field of clothes and textile such as knitting etc...

A questionnaire was used to identify and perform the propensity of the students towards the skills they need to learn and applying the training program to develop their knowledge and handcraft skills.

The blind females' skills were evaluated by a pre-post test form besides an evaluation card which includes questions in knowledge and skills related to clothes and textile. The evaluation tools were reviewed and commended by specialist arbitrators.

The results of the field study indicated that all the blind females have no knowledge about the different skills related to clothes and textile. After applying the training program, the results revealed that $88.89 \%$ of blind females acquired sufficient knowledge about the clothes and textile skills.

The study also revealed sound attraction of the blind females towards the combined textile handcraft by using the sensation of touch. The rough and smooth silk strips are used to produce different technical parts which were sold at exhibitions.

Some of the handmade skills were called off such as knitting, because of non-acceptance from the blinds as well as unsuitability to the case of handicapped.

The pre-post test for the conductive parts were measured, besides the evaluation card for the blinds handcraft skills which was reviewed by the specialist arbitrators in the field of clothes and textile. 


\section{الملحقات}

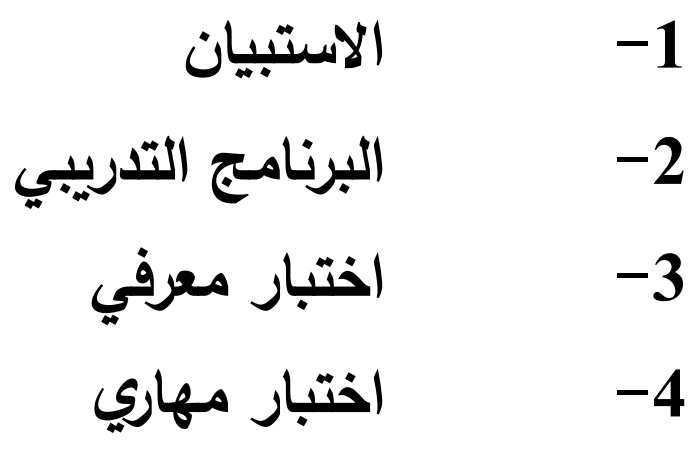


منا موسى غالب وأخرون : تنمية معارف ومهارات المكفوفات في بجال المنسوجات والملابس من خلال برنامج تدريبي

\begin{tabular}{|c|c|c|c|c|c|c|}
\hline ( & ) & ( & ) & ( & ) & مسطرة \\
\hline ( & ) & ( & ) & ( & ) & دبابيس \\
\hline ( & ) & ( & ) & ( & ) & كربون \\
\hline ( & ) & ( & ) & ( & ) & كستبان \\
\hline ( & ) & ( & ) & ( & ) & روليت \\
\hline ( & ) & ( & ) & ( & ) & مارك \\
\hline ( & ) & ( & ) & ( & ) & باترون \\
\hline
\end{tabular}

سـابعاً: مـدى إملام المككفوفات بالمصططلحات المختلفـة في مجـال الملابسس
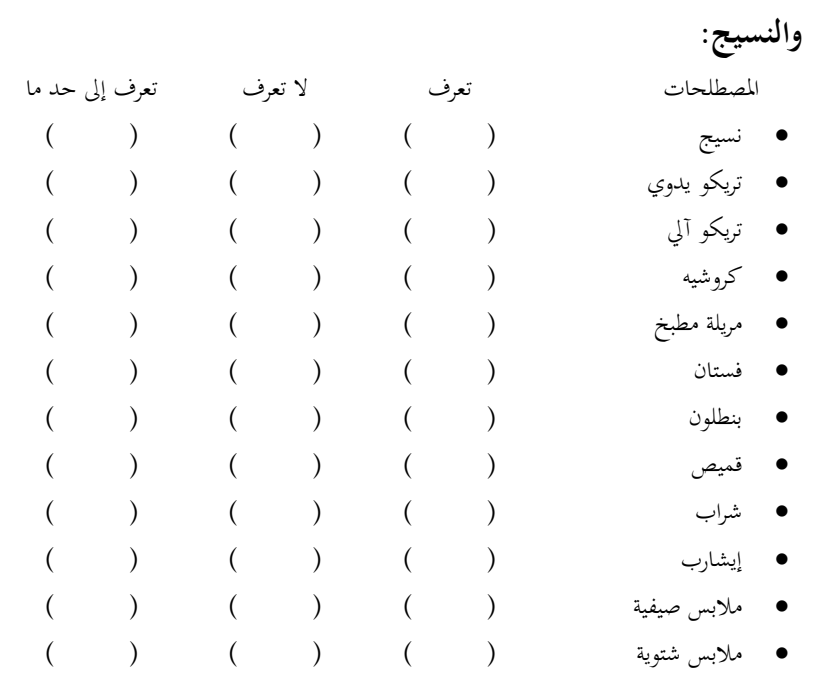

ثامناً: مدى إلمام المكفوفات بالمصطلحات المختلفة الخاصة بإكسسوارات

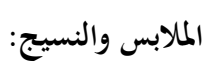

\begin{tabular}{|c|c|c|c|c|c|}
\hline \multirow{2}{*}{\multicolumn{3}{|c|}{ تعرف إلى حد ما }} & & & تعرف \\
\hline & & & تعرן & & \\
\hline ( & ) & ( & ) & ( & ) \\
\hline ( & ) & ( & ) & ( & ) \\
\hline ( & ) & ( & ) & ( & ) \\
\hline ( & ) & ( & ) & ( & ) \\
\hline ( & ) & ( & ) & ( & ) \\
\hline ( & ) & ( & ) & ( & ) \\
\hline ( & ) & ( & ) & ( & ) \\
\hline ( & ) & ( & ) & & ) \\
\hline ( & ) & ( & ) & ( & ) \\
\hline
\end{tabular}

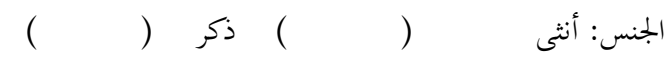

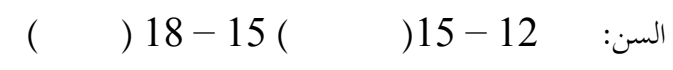

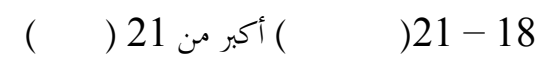

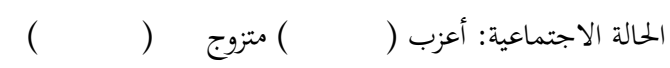

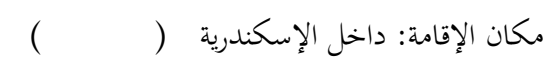

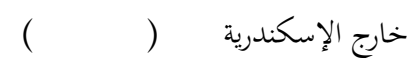

ثانياً: معلومات عن مهارات المكفوفات في مجال الملابس والنسيج:

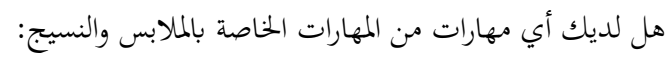

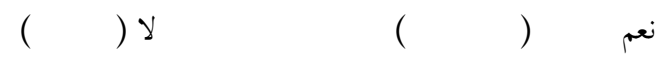
إذاكانت الإجابة بنعم أذكري المهارات التي تجيديها؟
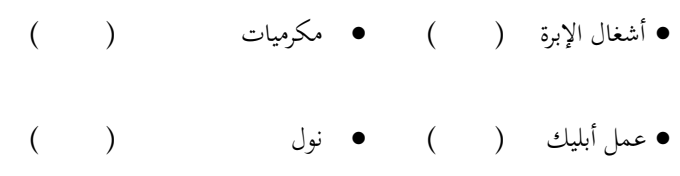

خامساً: أنواع الألياف النسيجية:

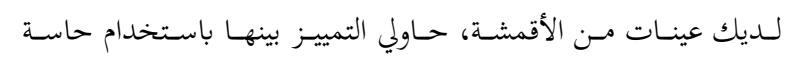
اللمس؟

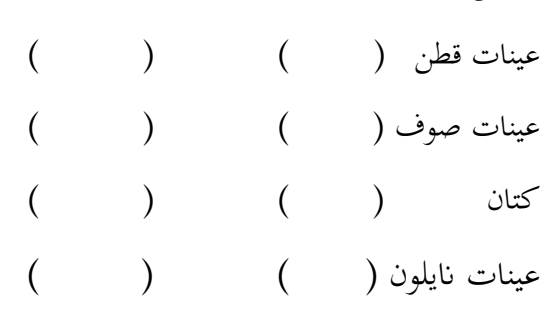
سادساً: الأدوات المستخدمة في مجال الملابس والنسيج لديك عينات من الأدوات المستخدمة في بجال الملابس والنسيج : فرقي

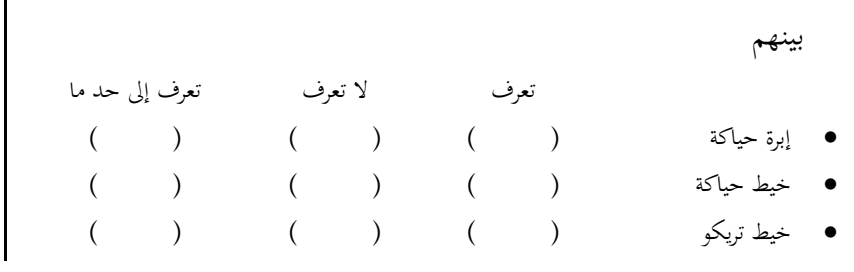




$$
\text { مجلة الإسكندرية للتبادل العلمى - (بجلد } 28 \text { العدد 3) يوليو - سبتمبر } 2007
$$

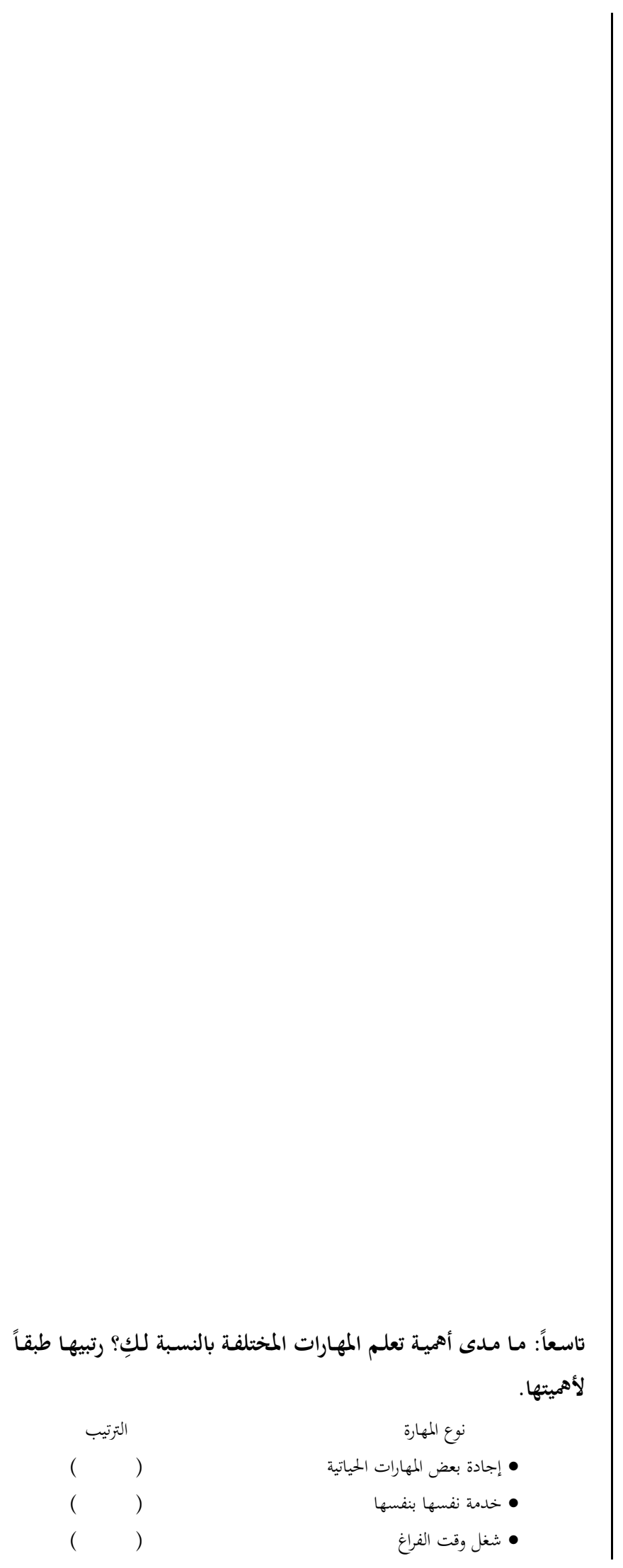


منا موسى غالب وأخرون : تنمية معارف ومهارات المَّ وفات في بجال المنسوجات والملابس من خلال برنامج تدريبي

2- قومي بعمل إكسسوار ودرة باستخدام عجينة السيراميك

3- باستخدام خيوط الساتان الناعم والخشن قومي بعمل مفرش باستخدام

تركيب نسجي سادة 1/1 1/

4- باستخدام خيوط اللاسيه قومي بتغطية علبة المناديل التي أمامك

5- باستخدام خيوط المكرمية قومي بعمل مفرش لمنضدة صغيرة.

6- باستخدام خيوط المكرمية قومي بعمل معلقة لحائط

7- 1 باستخدام خيوط المكرمية قومي بعمل سبت يصلح لوضع التليفون.
• • • الاشتراك فيلة للكسب من خلال مشروع صغير الإعاقة وإثبات الذات

أولاً: الاختبار المعرفي:

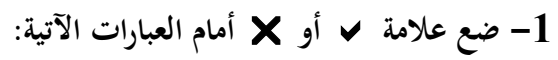

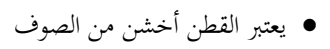

•

• ت تتميز خيوط اللاسيه بزيادة سمكها عن خيوط المكرمية

• • هناك فرق بين الملابس الصيفية والشتوية

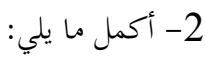

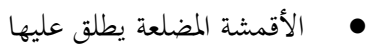

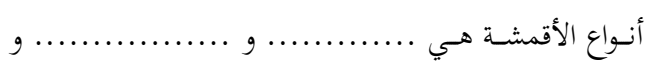

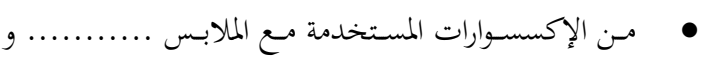

5- كيف تفرقي بين شرائط الساتان

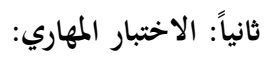

1- باستخدام اللمس فرقي بين أنواع الخيوط المختلفة. 
مجلة الإسكندرية للتبادل العلمى - (بجلد 28 العدد 3) يوليو - سبتمبر 2007 